\title{
PURSED LIPS BREATHING TERHADAP PENINGKATAN ARUS PUNCAK EKSPIRASI (APE) PASIEN ASMA
}

\author{
Dian Kartikasari' ${ }^{1}$, Emi Nurlaela ${ }^{2}$ \\ ${ }^{1,2}$ Program Studi Sarjana Keperawatan dan Program Pendidikan Profesi Ners Fakultas Ilmu Kesehatan \\ Universitas Muhammadiyah Pekajangan Pekalongan \\ Email: dian.kartikasari1989@gmail.com
}

\begin{abstract}
ABSTRAK
Latar belakang: Asma salah satu gangguan pada sistem pernapasan yang ditandai dengan sesak napas, batuk dan mengi. Salah satu penatalaksanaan yang bisa dilakukan pada pasien asma adalah dengan tindakan nonfarmakologis pursed lips breathing. Tujuan: Penelitian untuk mengetahui pengaruh pursed lips breathing dalam terhadap peningkatan Arus Puncak Ekspirasi (APE) pada pasien asma. Metode: Penelitian ini menggunakan metode quasi experiment pretest-posttest with control group. Jumlah subyek penelitian 20 orang yang dibagi menjadi 2 kelompok yaitu 10 kelompok intervensi dan 10 kelompok kontrol. Pengukuran APE menggunakan philips respironics peak flow meter. Data dianalisis dengan uji Mann-Whitney. Hasil: Terdapat peningkatan APE pasien asma dengan $p$ value 0,001 ( $p<0,05)$. Pursed lips breathing membantu memperbaiki transportasi oksigen, melatih otot respirasi serta meningkatkan pengeluaran karbondioksida. Kesimpulan: Diharapkan perawat mengaplikasikan pursed lips breathing sebagai intervensi keperawatan mandiri pasien asma. Peneliti selanjutnya dapat melakukan penelitian terkait pursed lips breathing pada pasien asma.
\end{abstract}

Kata kunci: APE, Asma, Pursed lips breathing

\begin{abstract}
Background: Asthma is a disorder of the respiratory system characterized by shortness of breath, coughing and wheezing. One of the treatments that can be done in asthmatic patients is pursed lips breathing non-pharmacological. Objective: This study was to determine the effect of deep pursed lips breathing on increasing Peak Expiratory Flow (PEF) in asthmatic patients. Methods: This study used a quasi-experimental pretest-posttest method with control group. The number of research subjects was 20 people who were divided into 2 groups, namely 10 intervention groups and 10 control groups. PEF measurement using philips respironics peak flow meter. Data were analyzed by Mann-Whitney test. Results: There was an increase in PEF in asthmatic patients with p value $0.001(\mathrm{p}<0.05)$. Pursed lips breathing helps improve oxygen transportation, trains respiratory muscles and increases carbon dioxide expenditure. Conclusion: Nurses are expected to apply pursed lips breathing as an independent nursing intervention for asthma patients. Further researchers can conduct research related to pursed lips breathing in asthma patients.
\end{abstract}

Keywords: Asthma, PEF, Pursed lips breathing 


\section{Latar Belakang}

Asma berasal dari bahasa Yunani yang berarti terengah-engah dan serangan pendek. Asma sekarang hanya ditujukan untuk keadaan mengenai respon abnormal saluran nafas terhadap berbagai rangsangan mengenai penyempitan jalan nafas yang meluas (Sylvia \& Lorraine, 2006 dalam Usman et al., 2015)

Gejala yang terjadi pada pasien asma adalah sesak napas, mengi dan batuk yang disebabkan karena vasokonstriksi pada jalan napas dan inflamasi pada bronchus (Juhariyah et al., 2012). Gejala yang ditimbulkan pada pasien asma dapat menyebabkan pasien tidak dapat melakukan aktifitas sehari-hari. Selain itu asma dapat menimbulkan kekambuhan yang bisa berakibat pada kematian (Kartikasari et al., 2019).

Prevalensi asma menurut World Health Organization (WHO) tahun 2016 sekitar 235 juta dengan angka kematian lebih dari $80 \%$ di negara-negara berkembang. Berdasarkan data WHO (2002) dan GINA (2011) memaparkan bahwa diseluruh dunia diperkirakan 300 juta orang menderita asma dan diperkirakan di tahun 2025 jumlah pasien asma meningkat dengan mencapai angka 400 juta jiwa (Kementerian, 2013).

Penatalaksanaan yang bisa dilakukan pada pasien asma dapat berupa tindakan farmakologis dan tindakan nonfarmakologis. Salah satu tindakan yang bisa dilakukan berupa nonfarmakologis adalah latihan pernapasan (Atmoko et al., 2011). Latihan pernapasan dilakukan untuk melatih cara melakukan pernapasan dengan baik dan benar, meningkatkan fungsi pernapasan, meningkatkan sirkulasi, serta meningkatkan kualitas hidup pasien dengan gangguan sistem pernapasan. Pada pasien asma, latihan pernapasan selain digunakan untuk memperbaiki pernapasan juga mempunyai tujuan untuk melatih pasien pada saat terjadi serangan (Atmoko et al., 2011).

Salah satu tindakan nonfarmakologis yang bisa dilakukan pada pasien asma dengan latihan napas berupa pursed lips breathing. Pursed lips breathing merupakan salah satu teknik latihan pernapasan yang dilakukan dengan bernapas melalui hidung dan mengeluarkannya melalui mulut dengan bentuk mulut seperti meniup lilin. Pursed lips breathing akan meningkatkan pertukaran udara di paru sehingga memudahkan pasien asma dalam bernapas. Pursed lips breathing dapat memperlancar proses oksigenasi di dalam tubuh (Widowati, 2010).

\section{Metode}

Penelitian ini merupakan penelitian kuantitatif menggunakan metode quasi eksperimen dengan bentuk pretest-posttes with control group dimana pada kelompok pertama diberikan obat asma dan tambahan intervensi pursed lips breathing dan kelompok kedua adalah kelompok kontrol yang diberikan obat asma.

Sampel penelitian berjumlah 20 subjek penelitian yang dibagi menjadi dua kelompok, kelompok intervensi dan kelompok kontrol. 
Kriteria inklusi pada penelitian ini adalah pasien asma dan tidak sedang dalam serangan asma.

Kriteria ekslusi pada penelitian ini adalah wanita dalam keadaan hamil. Pengukuran APE menggunakan Philips respironics peak flow meter. Kelompok intervensi dan kelompok kontrol di ukur APE pre test. Kelompok intervensi diberikan obatobatan sesuai advice dokter dan tambahan intervensi pursed lips breathing dalam selama 15 menit, sedangkan kelompok kontrol hanya diberikan obat-obatan sesuai advice dokter.

\section{Hasil}

Dari hasil penelitian dapat dijelaskan tentang APE pasien asma pada kelompok intervensi dan kelompok kontrol seperti ditampilkan pada Tabel 1.

Tabel 1. APE Pasien Asma pada Kelompok Intervensi dan Kelompok Kontrol

\begin{tabular}{|c|c|c|c|c|}
\hline Variabel & $\mathbf{n}$ & $\begin{array}{c}\text { Rerata } \pm S \\
\text { D }\end{array}$ & $\begin{array}{l}\text { Min- } \\
\text { Maks }\end{array}$ & $\begin{array}{c}P \\
\text { value }\end{array}$ \\
\hline \multicolumn{5}{|c|}{ Kelompok Intervensi } \\
\hline APE & \multirow{4}{*}{10} & $200,10 \pm 2$ & $110-$ & \multirow{4}{*}{0,001} \\
\hline sebelum & & 0,50 & 200 & \\
\hline APE & & $150,57 \pm 2$ & $150-$ & \\
\hline setelah & & 1,34 & 250 & \\
\hline \multicolumn{5}{|c|}{ Kelompok Kontrol } \\
\hline APE & & $200,86 \pm 2$ & $120-$ & \multirow{4}{*}{0,003} \\
\hline sebelum & & 5,86 & 200 & \\
\hline APE & 10 & $125,00 \pm 3$ & $150-$ & \\
\hline setelah & & 0,68 & 220 & \\
\hline
\end{tabular}

Catatan: APE dalam L/menit

Rerata nilai APE kelompok intervensi sebelum dilakukan intervensi dapat disimpulkan bahwa terdapat rerata perbedaan nilai APE yang signifikan pada kelompok intervensi sebelum dan sesudah intervensi. Rerata nilai APE kelompok kontrol dapat disimpulkan bahwa terdapat rerata perbedaan nilai APE yang signifikan pada kelompok kontrol sebelum dan sesudah intervensi.

\section{Pembahasan}

Pada pasien asma mengalami pernapasan yang buruk. Hal ini disebabkan karena adanya penyempitan pada diafragma (Adhi Pradini, 2011). Pada penelitian ini terjadi peningkatan APE yang signifikan pasien asma setelah melakukan pursed lips breathing pada kelompok intervensi.

Latihan pernapasan dengan pursed lips breathing bukan hanya membantu memperbaiki keadaan sesak pada pasien, tetapi juga dapat meningkatkan fungsi paru salah satunya arus puncak ekspirasi. Gejala yang ditimbulkan pada pasien asma adalah batuk, sesak napas dan bunyi napas wheezing. Oleh karena itu pasien asma dengan kondisi tersebut harus mendapatkan penanganan sejak dini untuk mencegah kerusakan paru yang lebih lanjut (Astuti et al., 2015).

Pursed lips breathing membantu memperbaiki transportasi oksigen, melatih otot respirasi serta meningkatkan pengeluaran karbondioksida yang terperangkap di dalam paru sehingga meningkatkan ruang rugi paru dan membantu mengurangi gejala yang ditimbulkan pada pasien asma. Penurunan gejala pada pasien asma tersebut merupakan salah satu indikator keberhasilan penatalaksanaan pasien asma (Amira Permata Sari Tarigan \& Juliandi, 2018).

Pursed lips breathing merupakan salah satu latihan pernapasan yang mudah dilakukan 
sendiri di rumah ataupun dimanapun pasien berada, dengan gerakan yang tidak sulit, dengan biaya yang murah, serta tidak menimbulkan efek Pursed lips breathing bisa dilakukan dalam waktu 15 menit (Ratnaningtyassih et al., 2016).

\section{Kesimpulan}

Terdapat peningkatan APE lebih tinggi pada kelompok pasein asma yang mendapatkan pursed lips breathing dibandingkan dengan kelompok pasien yang tidak mendapatkan pursed lips breathing samping pada pasien asma.

\section{Ucapan Terima kasih}

Ucapan terima kasih kepada Lembaga Penelitian dan Pengabdian Masyarakat Universitas Muhammadiyah Pekajangan Pekalongan.

\section{Daftar Pustaka}

Adhi Pradini, P. (2011). Terhadap Arus Puncak Ekspirasi Pada Wanita Usia Universitas Diponegoro Tahun 2011. 1-12.

Amira Permata Sari Tarigan, \& Juliandi. (2018). Pernafasan Pursed Lip Breathing Meningkatkan Saturasi Oksigen Penderita Penyakit Paru Obstruktif Kronis (PPOK) Derajat II. Jurnal Keperawatan Indonesia, 1(2), 39-46.

Astuti, S. I., Arso, S. P., \& Wigati, P. A. (2015). Pursed Lips Breathing Terhadap Peningkatan Arus Puncak Ekspirasi (Ape) Pasien Asma. Analisis Standar Pelayanan Minimal Pada Instalasi Rawat Jalan Di RSUD Kota Semarang, 3, 103-111.

Atmoko, W., Khairina, H., Faisal, P., \&
Bobian, E. T. (2011). Prevalens Asma Tidak Terkontrol dan Faktor-Faktor yang Berhubungan dengan Tingkat Kontrol Asma di Poliklinik Asma Rumah Sakit Persahabatan, Jakarta.

Juhariyah, S., Djajalaksana, S., Sartono, T. R., Ridwan, M., \& Sakit Saiful Anwar, R. (2012). Efektivitas Latihan Fisis dan Latihan Pernapasan pada Asma Persisten Sedang-Berat. The Efectivity Physical Exercise and Breathing Exercise on Persistent moderate to severe Asthma. In $J$ Respir Indo (Vol. 32, Issue 1).

Kartikasari, D., Jenie, I. M., \& Primanda, Y. (2019). Latihan Pernapasan Diafragma Meningkatkan Arus Puncak Ekspirasi (Ape) Dan Menurunkan Frekuensi Kekambuhan Pasien Asma. Jurnal Keperawatan Indonesia, 22(1), 53-64. https://doi.org/10.7454/jki.v22i1.691

Kementerian, K. (2013). Pusat data dan informasi RI. In Kementerian, Kesehatan (pp. 1-8).

Ratnaningtyassih, Arif, S., Jurusan, D., Poltekkes, K., \& Semarang, K. (2016). Efektifitas Deep Breathing terhadap Penurunan Frekuensi Pernapasan pada Pasien PPOK di RSUD Ambarawa. Jurnal Ilmu Keperawatan Dan Kebidanan (JIKK), 5(1), 1-7.

Sylvia, \& Lorraine. (2006). Asma bronkial. Dalam: Patofisiologi Konsep Klinis Proses-Proses Penyakit. Jakarta:EGC.

Usman, I., Chundrayetti, E., \& Khairsyaf, O. (2015). Faktor Risiko dan Faktor Pencetus yang Mempengaruhi Kejadian Asma pada Anak di RSUP Dr. M. Djamil Padang. Jurnal Kesehatan Andalas, 4(2), 392-397. https://doi.org/10.25077/jka.v4i2.260

Widowati, R. I. A. (2010). Efektivitas PursedLip Breathing Exercise Terhadap Frekuensi Serangan Pasien Ppok Skripsi dengan judul: Efektivitas Pursed-Lip Breathing Exercise Terhadap Frekuensi Serangan Pasien PPOK. Fakultas Kedokteran, Universitas Sebelas Maret, 
1-62. 